\title{
Structure Change of Condensed Phosphate Ions upon Devitrification of Magnesium Metaphosphate and Calcium Magnesium Metaphosphate Glasses
}

\author{
By
}

Hiroshi KAWAZOE, Masayoshi IKEDA* and Takafumi KANAZAWA

(Department of Industrial Chemistry, Faculty of Technology, Tokyo Metropolitan University)

\section{メ夕燐酸マグネシウムガラスおよびメタ燐酸カルシウムマグネシウム ガラスが失透する時の, 縮合燐酸イオンの構造変化}

\author{
川副博司・池田正義・金澤孝文 \\ (東京都立大学 工学部 工業化学教室)
}

It seems magnesium metaphosphate glass containing a slight amount of ring phosphates changes into a crystalline substance known as magnesium metaphosphate by heat-treatment ${ }^{1)}$. The composition of crystalline magnesium metaphosphate is magnesium tetrametaphosphate having a cyclic structure $^{2), 3)}$. This tetrametaphosphate is considered to be an only known crystalline condensed phosphate of magnesium. Thus the devitrification process of the glass is expected to involve a drastic change in structure of the phosphate ions from a linear highpoly-form to the cyclic tetrametaform.

In the present report, infra-red(IR) absorption spectra for the glasses were measured to clarify the structure-change of the phosphate anions on devitrification of $\mathrm{MgP}_{2} \mathrm{O}_{6}$ and $\mathrm{CaMg}\left(\mathrm{P}_{2} \mathrm{O}_{6}\right)_{2}$ glasses: Detailed method of preparation of the glasses was described in the previous paper ${ }^{1)}$. The IR spectra were obtained with a Hitachi EPI-2 IR spectrometer using $\mathrm{KBr}$-disc technique.

The compositions of the glass samples used and the crystalline phases formed by thermal treat. ment of the respective glasses are given in Table 1. Figs. 1 and 2 show IR spectra for the glasses and their devitrified materials, respectively. The spectra for the $\mathrm{CaO}-\mathrm{P}_{2} \mathrm{O}_{5}(\mathrm{C}-\mathrm{P})$ and $\mathrm{MgO}-\mathrm{P}_{2} \mathrm{O}_{5}$ (M-P) glasses agreed with those reported by Naruse, Abe and Inoue ${ }^{4)}$. In Fig. 1 four broad absorption bands were recognized for the three systems in common; their peaks appeared at about (a) $1300 \mathrm{~cm}^{-1}$, (b) $1100 \mathrm{~cm}^{-1}$, (c) $920 \mathrm{~cm}^{-1}$, and (d) $750 \mathrm{~cm}^{-1}$. Following previous researchers $^{2), 5) ~ 7)}$, assignment of those absorption bands could be given. The band (a) is thought to be attributable to $\mathrm{P}=\mathrm{O}$ stretching (asymmetrical stretching of the middle $\mathrm{PO}_{2}$ groups in linear chains and/or in ring phosphates), the band (b) to ionic $\mathrm{P}-\mathrm{O}^{-}$stretching in the middle $\mathrm{PO}_{2}$ groups and/or the end $\mathrm{PO}_{3}$ groups, the band (c) to $\mathrm{P}-\mathrm{O}-\mathrm{H}$ bending and/or P-O-P stretching, and the band (d) to P-O-P bending. From appearance of the bands (a) and (d), the phosphate ions in these glasses are considered to have a polymerized structure, which is either linear chains with a polymerization degree $\bar{n} \geqq 3$ or cyclic form.

In Fig. 2, the broad peaks at about $900 \mathrm{~cm}^{-1}$

Table 1. Composition of glass samples and crystalline phases formed on devitrification of the glasses.

\begin{tabular}{|c|c|c|c|}
\hline $\begin{array}{l}\text { Sample } \\
\text { number }\end{array}$ & System & $\begin{array}{l}\mathrm{RO} / \mathrm{P}_{2} \mathrm{O}_{5}^{\mathrm{a})} \\
\text { (mole ratio) }\end{array}$ & $\begin{array}{l}\text { Crystalline phases present } \\
\text { in devitrified samples }\end{array}$ \\
\hline 1 & $\mathrm{CaO}-\mathrm{P}_{2} \mathrm{O}_{5}$ & $55 / 45$ & $\begin{array}{l}\text { trömelite, } \beta \text {-calcium meta- } \\
\text { phosphate }\end{array}$ \\
\hline 2 & " & $50 / 50$ & $\beta$-calcium metaphosphate \\
\hline 3 & $"$ & $40 / 60$ & " \\
\hline 4 & $\mathrm{MgO}-\mathrm{P}_{2} \mathrm{O}_{5}$ & $60 / 40$ & $\begin{array}{l}\text { magnesium pyrophosphate, } \\
\text { magnesium metaphosphate }\end{array}$ \\
\hline 5 & $"$ & $50 / 50$ & magnesium metaphosphate \\
\hline 6 & $"$ & $40 / 60$ & " \\
\hline 7 & $\left.\mathrm{CaO}-\mathrm{MgO}-\mathrm{P}_{2} \mathrm{O}_{5}{ }^{\mathrm{c}}\right)$ & $60 / 40$ & $?$ \\
\hline 8 & " & $50 / 50$ & magnesium metaphosphate \\
\hline 9 & $"$ & $40 / 60$ & $?$ \\
\hline
\end{tabular}

a) $\mathrm{RO}: \mathrm{CaO}, \mathrm{MgO}$ or $\mathrm{CaO}+\mathrm{MgO}$

b) The glasses in the systems $\mathrm{CaO}-\mathrm{P}_{2} \mathrm{O}_{5}, \mathrm{MgO}-\mathrm{P}_{2} \mathrm{O}_{3}$ and $\mathrm{CaO}$ $-\mathrm{MgO}-\mathrm{P}_{2} \mathrm{O}_{5}$ were heat-treated above $700^{\circ}, 780^{\circ} \mathrm{C}$ and $755^{\circ} \mathrm{C}$, respectively.

c) $\mathrm{CaO} / \mathrm{MgO}=1$ (mole ratio) 


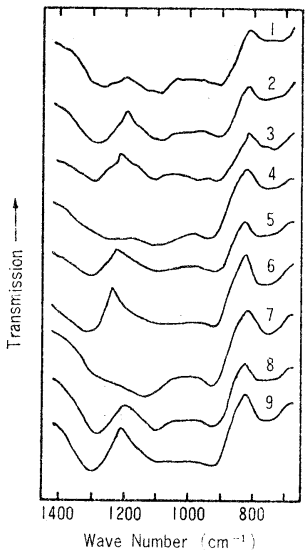

Fig. 1. Infra-red absorption spectra for phosphate glass samples. The attached figure denotes sample number.

for $\mathrm{C}-\mathrm{P}$ glasses and at about $920 \mathrm{~cm}^{-1}$ for $\mathrm{M}-\mathrm{P}$ glasses diminished, and one of the characteristic peaks due to the end $\mathrm{PO}_{3}$ groups ${ }^{2), 5), 7)}$ appeared at $940 \sim 950 \mathrm{~cm}^{-1}$ for C-P system (Fig. 2(1) (3)) and at about $970 \mathrm{~cm}^{-1}$ for $\mathrm{M}-\mathrm{P}$ system (Fig. 2 (4)). These facts suggest that a condensationdehydration reaction was formed between the end $\mathrm{P}-\mathrm{O}-\mathrm{H}$ groups in the linear chains upon devitrification $^{4}$. The formation of the above end groups was due to the presence of residual $\mathrm{H}_{2} \mathrm{O}^{4}$ ) in the glass. Thus it can be inferred that the phosphates in the starting glasses take the form of linear anion which was also detected by the paper chromatography carried out previously ${ }^{1)}$.

As stated above partly, the peculiar peaks of the end $\mathrm{PO}_{3}$ groups in the chains (near $950 \mathrm{~cm}^{-1}$ ) and of the middle $\mathrm{PO}_{2}$ groups (in the vicinity of $1300 \mathrm{~cm}^{-1}$ and $700 \sim 800 \mathrm{~cm}^{-1}$ ) appeared in the spectra for the devitrified materials in C-P system. Therefore the crystalline phase in the specimen was viewed as a linear polyphosphate of calcium.

In the case of $\mathrm{M}-\mathrm{P}$ system, the peaks attributed to the middle $\mathrm{PO}_{2}$ groups were noticed in the spectra for the three devitrified substances (Fig. $2(4) \sim(6))$. The peak characteristic of the end $\mathrm{PO}_{3}$ groups (near $970 \mathrm{~cm}^{-1}$ ) was seen in the spectrum for the specimen with $M / P=60 / 40$, whereas such a peak was not observed for the sample with $M / P=50 / 50$ (Fig. 2 (4), (5)). Hence, it can be concluded that at least a part of the phosphates in the devitrified material with $M / P=60 /$ 40 has linear chain structures and those with $\mathrm{M}$ / $\mathrm{P}=50 / 50$ take cyclic forms. The spectrum for the No. 5 sample agreed exactly with that of magnesium tetrametaphosphate (Fig. $2\left(5^{\prime}\right)$ ). After all the structure-change of the phosphate anions in the $\mathrm{MgP}_{2} \mathrm{O}_{6}$ glass upon devitrification has been

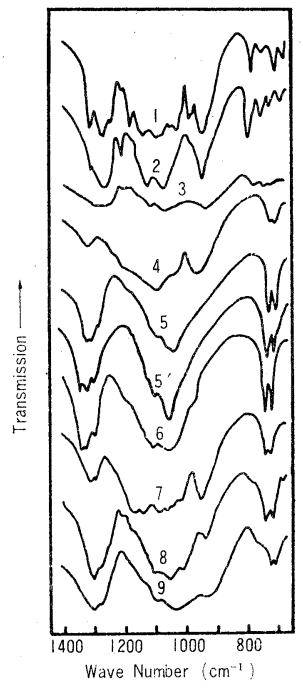

Fig. 2. Infra-red absorption spectra for devitrified materials formed from the corresponding phosphate glasses. The attached figure denotes sample number. $5^{\prime}$ is the spectrum for magnesium tetrametaphosphate quoted from ref. 2).

confirmed by means of IR spectra.

The spectrum for the devitrified sample of the $\mathrm{CaMg}\left(\mathrm{P}_{2} \mathrm{O}_{6}\right)_{2}$ glass (Fig. $2(8)$ ) was similar to that for the crystallized $\mathrm{MgP}_{2} \mathrm{O}_{6}$ glass. In this case, however, several peaks were recognizable clearly. They are the small peaks at wave numbers 785 , $940,1210 \mathrm{~cm}^{-1}$ and $1010 \mathrm{~cm}^{-1}$. The first three peaks may be due to contribution from the linear calcium polyphosphates. The last peak could not be assigned. Thus, it is stated that the phosphate ions in the devitrified material with the composition $\mathrm{CaMg}\left(\mathrm{P}_{2} \mathrm{O}_{6}\right)_{2}$ consist of both linear and cyclic types.

A part of this paper was read at No. 20 Annual Meeting of the Chemical Society of Japan, April 1967.

\section{References}

1) T. Kanazawa, M. Ikeda and H. Kawazoe, YogyoKyokai-Shi 77, 163 (1969).

2) E. Steger, Z. anorg. allgem. Chem. 294, 146(1958).

3) A.B. Bekturov, D.Z. Serazetinov and Yu.A. Kushnikov, Zh. Neorg. Khim. 12, 2355 (1967).

4) A. Naruse, Y. Abe and H. Inoue, Yogyo-KyokaiShi 76, 36 (1968).

5) D.E.C. Corbridge and E.J. Lowe, J. Chem. Soc., 493, 4555 (1954).

6) W. Bues and H.W. Gehrke, Z. anorg. allgem. Chem. 288, 291 (1956).

7) E. Steger and A. Simon, ibid. 294, 1 (1958).

[Received October 4, 1973] 